\title{
ANALYSIS OF FACTORS FORMING COMPETITIVE BUSINESS ENVIRONMENT IN CROSS-BORDER REGION
}

\author{
Lilita Ābele ${ }^{1}$, Diāna Līduma ${ }^{2}$, Inese Leitāne ${ }^{3}$, Anita Mežinska ${ }^{4}$ \\ ${ }^{1}$ University of Liepaja, Latvia, lilita.abele@liepu.lv \\ ${ }^{2}$ University of Liepaja, Latvia, diana.liduma@liepu.lv \\ ${ }^{3}$ University of Liepaja, Latvia, inese.leitane@liepu.lv \\ ${ }^{4}$ University of Liepaja, Latvia, anita.mezinska@liepu.lv \\ cross'ref http://dx.doi.org/10.5755/j01.em.17.4.2993
}

\begin{abstract}
Research problem: For Latvia - Lithuania borderland is characteristic continued low competitiveness. One of ways for increasing competitiveness is improving business growth instruments.

The aim of research is identification and evaluation of strength and weaknesses of competitiveness of business environment in Kurzeme region by researching factors forming competitiveness and query opinion of entrepreneurs.

It is developed appropriate methodology for comparison of borderland regions. Research distinguished four groups of parameters:

1. Factors of local business environment.

2. Factors of demand.

3. Factors of companies` competitiveness.

4. Factors of external environment, influencing business growth.

Practical research consists of internet survey (150 entrepreneurs). The obtained outcome is expressed in figures.

Research methodology: analysis of documents, statistical data, questionnaire, and factors.

Conclusions: research identified the character of Kurzeme region, it business environment. Research elucidated viewpoint of entrepreneurs, their reasons of exploiting business support instruments. Research evaluated strength and weaknesses of business environment competitiveness.

Keywords: borderland, business environment, development, factors.

JEL Classification: R110.
\end{abstract}

\section{Introduction}

For the study the author has chosen Kurzeme region, located in West side of Latvia and in the South it borders with Klaipeda region, Lithuania. The researched region, with the total space $\sim 136008 \mathrm{~km}^{2}$, occupies more than one fifth $(21.1 \%)$ of the total state's territory, and it is the third largest region in Latvia. Region has the longest seashore of Baltic Sea and Gulf of Riga. One of region's most characteristic features is the large amount of those territories that are located near the seashore- deepest domestic district is located only $100 \mathrm{~km}$ from the seashore. (Kurzeme Planning Region, 2012).

The closeness of the sea has a great importance in the development of the region, since it contributes the economic cooperation with other countries. The convenient geographical location ensures a transportation corridor for both Europe and CIS country cargo and passenger flows, but the land in the corresponding region mainly is used for forestry and agricultural needs.

Kurzeme region is considered as frontier region with the characteristic business environment specifics. "From the point of development frontier is spatially extensive and functional region, where territories or parts of them has a characteristic location near the state's borders, serving as a barrier. In the terrestrial frontier state's border directly affects the interconnected connections of territory, inhabitants and infrastructural network. Wherewith, all activities in state's frontier territories are restricted with particular space, socio-economic, cultural, political and institutional problems (Reǵionu attīstība Latvijā,2009).

Economic development in frontier regions always will be feasible artificially, since geographically the financial and economical potential always will be observed in the center on the territory (country's or region's) - theory of Bowman (1932). As a result, the frontier region's competitive capacity of business environment is an essential issue, which requires a solution and a strategic development progress in the cooperation level between local municipalities, also in international cross-border cooperation.

Estimating the frontier region's competitive capacity of business environment, it is important to understand the explanation and importance of this concept.

Development of economic thought, different apprehensions of competitiveness are represented, for example, comparative advantage theory emphasizes that for the state's development is necessary an efficient capacity- capital must be increased and improved, in order to increase the capacity of economic in its turn, Th. Malthus dealt with the economic development connected with the increase of population 
(Krugman,1994). He regarded that increasing the total output and at the same time the total income, income per capita will not increase so rapidly, wherewith, the quality of inhabitants must be promoted- level of education, health, expected level of living etc. After the industrial revolution an opinion evolves that the economic growth is based on business and innovation. One of world's leading experts of competitive capacity professor Michael Porter (Krugman,1994) notes that the competitive capacity of country, cluster, region, enterprise and the competitive capacity of a good is very distinctive. When an enterprise becomes uncompetitive, falls out the business turn-round, earns more less, perhaps becomes insolvent. A country cannot fall out of the business; it can make people happy or miserable (Krugman, 1994). Evaluation of regional competitiveness is difficult, since there is no unite conventional regional competitiveness and affecting factor's definition. Most frequently regional competitiveness is described as the ability to conquer the export market, involve people or capital, and it is dependant from the productivity level in the region. Competitiveness of region and state is based on education, innovation, reduction of employment by establishing more work places, in order to decrease social fund costs and motive people to work.

\section{Analysis of Indicators and Statistical Data for Evaluation of Business Environment Competitiveness in the Frontier Area}

In order to assess frontier id est., Kurzeme region's socio-economic development and perform statistical analysis of business environment's competitiveness characteristics, there are distributed 4 groups of factors:local business conditions, demand, external environment, competitiveness of an enterprise.

I. Local business environment factors and indicators, which reflects regional attraction and affects business development in it.

In this group are estimated human resource, its capital and infrastructure.

For the characterization of human resources, according to CSO (Central Statistical Office) data, there are used such indicators as number of residents, age structure and migration of inhabitants.

Table 1. Human resource characteristic, quantitative indicators in Kurzeme region (in accordance with CSO data)

\begin{tabular}{|c|c|c|c|c|}
\hline Year & $\begin{array}{c}\text { Number of } \\
\text { inhabitants } \\
\text { in region }\end{array}$ & $\begin{array}{c}\text { Long-term total net } \\
\text { migration per 10000 } \\
\text { inhabitants }\end{array}$ & $\begin{array}{c}\text { Inhabitants in } \\
\text { the giving } \\
\text { age, \% }\end{array}$ & $\begin{array}{c}\text { Population in dependent } \\
\text { age, total. per 100 giving } \\
\text { age inhabitants }\end{array}$ \\
\hline 2005 & 310673 & -30 & 62,8 & 26,28 \\
\hline 2006 & 308433 & -39 & 63,2 & 25,28 \\
\hline 2007 & 306053 & -42 & 64,2 & 24,12 \\
\hline 2008 & 303618 & -37 & 64,6 & 23,44 \\
\hline 2009 & 301621 & -32 & 65,3 & 22,75 \\
\hline 2010 & 299506 & -50 & 65,3 & 22,59 \\
\hline
\end{tabular}

Kurzeme region, according to the number of inhabitants and the specific weight in state's number of inhabitants, is the third within other regions (behind regions of Riga and Latgale).

The number of inhabitants in Latvia constantly decreases- in the corresponding period the number of inhabitants in Kurzeme shrank by 11.9 thousand (Reǵionu attīstība Latvijā 2010) because of migration - by 6 thousand people). The negative changes of the population in the region are smaller than in state's average (Regionu attīstîba Latvijā 2010), though, the main cause of emigration - work, establishes an increasing demand to the local market for a certain qualification professionals and, at the same time, there is a lapse of consumers - decreases the potential of the local market. In the Kurzeme region the inhabitant proportion of giving age in the corresponding period fluctuates around state's average indicator $(\sim 65 \%)$, but the number of inhabitants at the dependent age (0-14 years) has decreased. The relations between population age groups reflects the region's ageing process in the inhabitant composition and in the future the proportion of giving age inhabitants will reduce.

From the perspective of business environment's competitiveness, not only in the labor market available employee quantitative, but also qualitative indicators are essential, int.al, level of education. Number of students is a characteristic criterion of potential qualified employee accessibility.

In the Kurzeme region higher education institutions mainly are represented in major cities and they are located in largest region's centers- Liepāja and Ventspils, as well as Kuldīga. Kurzeme region's only university is located in Liepāja (University of Liepāja), but region's university college is located in Ventspils (Ventspils University College). In the region sufficiently well are represented various state and private higher 
education institution branch network. A significant tendency- already for the sixth year the amount of the students continues to decrease, endangering the total qualification level of labor force. A positive situation can be observed in the general society's inquisitiveness and in the inhabitant information technology usage field- each year in Latvia and in regions, int.al, in Kurzeme increases the amount of households using computers (58.6\% of households) and Internet.

By estimating the local business environment, characterized in the region available material resources are - capital and infrastructure.

As region's economic growth and development's potential indicator is used non-financial investments per capita in comparable prices, million LVL.

Table 2. Indicator dynamics of non-financial investments in Kurzeme region

\begin{tabular}{|c|c|c|}
\hline Year & $\begin{array}{c}\text { Non-financial investments per capita in } \\
\text { comparable prices, million LVL.* }\end{array}$ & $\begin{array}{c}\text { Dynamics, } \\
\text { \% }\end{array}$ \\
\hline 2005 & 1495,4 & 4,6 \\
\hline 2006 & 1563,6 & 0,6 \\
\hline 2007 & 1572,3 & 6,5 \\
\hline 2008 & 1674,7 & $-33,6$ \\
\hline 2009 & 1112,2 & No data \\
\hline 2010 & No data & \multicolumn{2}{|c|}{} \\
\hline
\end{tabular}

The economic breakdown in Kurzeme region has caused essential changes in the amount and structures of non-financial investments- the amount per capita in comparable prices considerably has decreased, especially in year 2009. At the end of the period, in Kurzeme region non-financial investment total amount compiles 334.3 million LVL (11.4\% of the average state's amount of non-financial investments).

The total transport infrastructure in the region has been established till year 1990, for that reason significant investments in the restoration is made, and two important local and international logistic nodes are developing, promoting potentialities of multimodal cargos shipment. The potential of regional ports and the total region's transport infrastructure, at a systematic development, could contribute the total regional growth of business and economics.

All transport types are represented in Kurzeme region- motor, railway, sea, air and pipeline, connecting the region with the main state and international roads. There are 2 international importance ports in Liepāja and Ventspils (operating in SEZ and Free port regimes) and 3 small ports. Though, the usage of transport and development potentialities can be estimated differently, for example, there has not been made and used infrastructure of inland-water transport, while port and sea transport development opportunities are promoted, air traffic has slow down, in the region are located 2 airports: in Liepāja and Ventspils. Comparing with Klaipeda region (Palanga airport), since year 2009 in Kurzeme there are no regular inland or international flights. This factor has negatively affected the development of region's different fields.

II. Demand factor and indicators, which reflects region's attraction and affects business growth in it.

This group's main factors are surveyed from the demand position of local and external market:

1) For the description of local market's demand such indicators are selected as population density, level of urbanization and material welfare. By evaluating the urbanization process in the region, the number of inhabitants in cities is analyzed, but for the assessment of material welfare the following indicators are used: the average monthly consumption expenditure per household member (LVL), and employee's average monthly wage in region (gross, LVL).

Table 3. Characteristic indicators of region's local market demand (according to CSO data)

\begin{tabular}{|c|c|c|c|c|}
\hline Year & $\begin{array}{c}\text { Population density } \\
\text { (Per capita 1 km2 } \\
\text { terit.) }\end{array}$ & $\begin{array}{c}\text { City's comparable } \\
\text { number of } \\
\text { inhabitants \% }\end{array}$ & $\begin{array}{c}\text { Average monthly } \\
\text { consumption expenditure } \\
\text { per household member, LVL }\end{array}$ & $\begin{array}{c}\text { Employee's average } \\
\text { monthly wage in } \\
\text { region (gross, LVL) }\end{array}$ \\
\hline 2005 & 22,8 & 41,8 & 106,94 & 209 \\
\hline 2006 & 22,7 & 41,9 & 141,19 & 249 \\
\hline 2007 & 22,5 & 42 & 183,15 & 334 \\
\hline 2008 & 22,3 & 42,2 & 206,37 & 408 \\
\hline 2009 & 22,2 & 42,2 & 175,35 & 386 \\
\hline 2010 & 22 & 42,1 & 163,81 & 382 \\
\hline
\end{tabular}

*estimated- both regions' major cities population proportion in region's number of inhabitants 
Decreasing the number of inhabitants, also decreases the population density, and in Kurzeme it is lower $\left(22\right.$ people $\left./ \mathrm{km}^{2}\right)$ than the national average $\left(34,8\right.$ people $\left./ \mathrm{km}^{2}\right)$. In the region a high urbanization level is observed. In both major cities lives $42 \%$ of region's total number of inhabitants. There is an explicit territorial population density and socio-economic inequality, since mainly dominates 2 economic activity centers (in terms of development of investment and infrastructure, manufacturing, trade and service fields); Liepāja and Ventspils.

Consumption expenditure in region per average monthly consumption expenditure per household member (in LVL) is lower than national average.

2) External market's demand tendencies in region are visible in the export amounts, port and airport activities in cargo and passenger transportations, as well as tourism attractiveness, by estimating the number of served people in hotels and other tourist accommodations.

Latvia's most relevant import and export trade partner is Lithuania, taking the first place within Latvia's external trade partners (Foreign Trade Statistics, 2011). Kurzeme region, as the Lithuania's frontier, has a significant role in the hedging of mutual cooperation.

In the service export Kurzeme region describes targeted development of tourism infrastructure and dynamic tourism flow. In the region constantly increases the amount of served tourists in the hotels and other tourist accommodations- in six year period it compiles $\sim 15 \%$ of Latvia's total number of served tourist. Economic breakdown and alteration of taxes have caused a negative result in tourism field, as well as political decisions in relation with air traffic and regional reform (introducing changes in tourism resource and product territorial management- financing, monitoring and marketing).

Also the economic breakdown's impact has rapidly reduced motor cargo transport. The turnover of Liepāja's port is stable with minimal average growth- $0.1 \%$ per year, but, in Ventspils port, since year 2007, the annual cargo turnover decreases. Estimating region's total cargo circulation (million tons per 1000 inhabitants), in the research period, it has decreased by average $2.8 \%$. In both ports the amount of sent cargo considerably exceeds the amounts of received cargo.

Overall local and external market demand factors, region's business potential is distinguishable, since analyzed region indicators in national average economic development phase basically has reached national average level. Tourism and transport fields must be developed, but local market's demand indicators are valuated weakly in the aspects of socio-economic inequality, population density and material welfare. There is a visible need to analyze region's total economic activity in context with national average politic and macroeconomic processes.

III. External environment factors and indicators, which affects business development.

In this certain factor group are included state's total indicators, which describes region's business macroeconomic and politically legal environments, as well as technological and science environments.

Macroeconomic environment can be evaluated according following indicators: GDP changes, annual inflation, national unemployment level.

Until year 2007, rapid national economy's development was observed, which depleted in year 2008, and in year 2009 faced a rapid decline, but in the first six month of year 2010 GDP decrease rates progressively raised (Regionu attīstība Latvijā. 2010). Such kind of economical fluctuations were followed by natural changes both in annual inflation and unemployment level indicators (Reǵionu attīstība Latvijā. 2010). Economic breakdown influenced business processes in each state's region business environment, causing a sharp decline in enterprise activity amounts and field structures.

In the research period, in Latvia has increased the labor force costs, as well as prices of all energy resources. Since year 2008, employee's monthly average gross wage in Latvia decreases and in year 2010 it compiles only $445 \mathrm{LVL}$. The steepest increase of energy resource had gas and electricity prices. Diesel prices have been fluctuating. Cost of labor force and energy resources present the increment of costs in business and total production rise in price.

Estimating current political and legal environment conditions for business, it is notable that Latvia's business mainly is concentrated in Riga and its regions. However, with different support mechanisms business development in regions is promoted, for example, in Kurzeme region are established specific economic zones and free-port territories (Liepāja and Ventspils), where enterprises can operate with various preferences. In Latvia generally are observed endeavors to evolve manufacturing and transport infrastructure- industrial parks, storehouses, communication technologies, ports and railway. Though, national support for science and technologies (R\&D costs from GDP, \%) in Latvia, contrary 2004-2006 
period tendencies, in the economic growth period (year 2007) has reduced to $0.63 \%$ from GDP, hence endangering the consummation of the set goal (1.5\%) in year 2010 (Cunksa, 2011).

IV. Enterprise's competitiveness factors and indicators, which reflects region's attractiveness and influences business growth in it.

Regional enterprises in their development have ensured that, by the amount of GDP, Kurzeme region is the second largest region in Latvia (behind Riga region), till year 2009, also a dynamic region's total value added indicator's growth was observed (inter alia, notable specific weight for industry), as well as, in the research period, the employment rates in Kurzeme, concerning other region perspectives, are considered high and corresponds to national average level (Regiionu attīstība Latvijā 2010).

Macroeconomic and politic environmental conditions for regional business are determinative, though, essential are region's entrepreneur motivation for self competitiveness increase, as well as separate enterprise activity rise, business structure and usage endeavors of business support instruments.

The structure of business describes the amount of functional economic units and proportion amount in region of large enterprises. As a result of economic growth (year 2007) in Kurzeme were 16230 economically active market sector statistical units, but the amount considerably shrank influenced by the economic breakdown- in year 2009 to 1000 inhabitants in Kurzeme were 54 economically active market sector statistical units (indicator was under the national average- 56.8). In Kurzeme on averega are located $7 \%$ of Latvia's large enterprises. In year 2009, this region faced a sharp decline of large enterprise amountlost 7 large enterprises. In total region has an explicit SME proportion, inter alia, also agricultural enterprise proportion within economically active market sector statistical units, and the majority fields of national economy in region are subjected to seasonal influence.

\section{The Activity of Entrepreneurs in Applying of Business Support Means and Increasing of Competitiveness}

For the assessment of business environment a practical research was applied, in the process of "Formation of methodological framework of regional business growth promotion (LT-LV)" project, in the summer of 2011 (apklausa.private.forms.survey), by carrying out a survey for regional enterprises. The aim of the survey was to determine the conditions necessary for business development in frontier region, ascertaining what kind of business support resources are used at the current moment and the need for new support resources.

In general, in the research period 150 enterprises from different fields were surveyed.

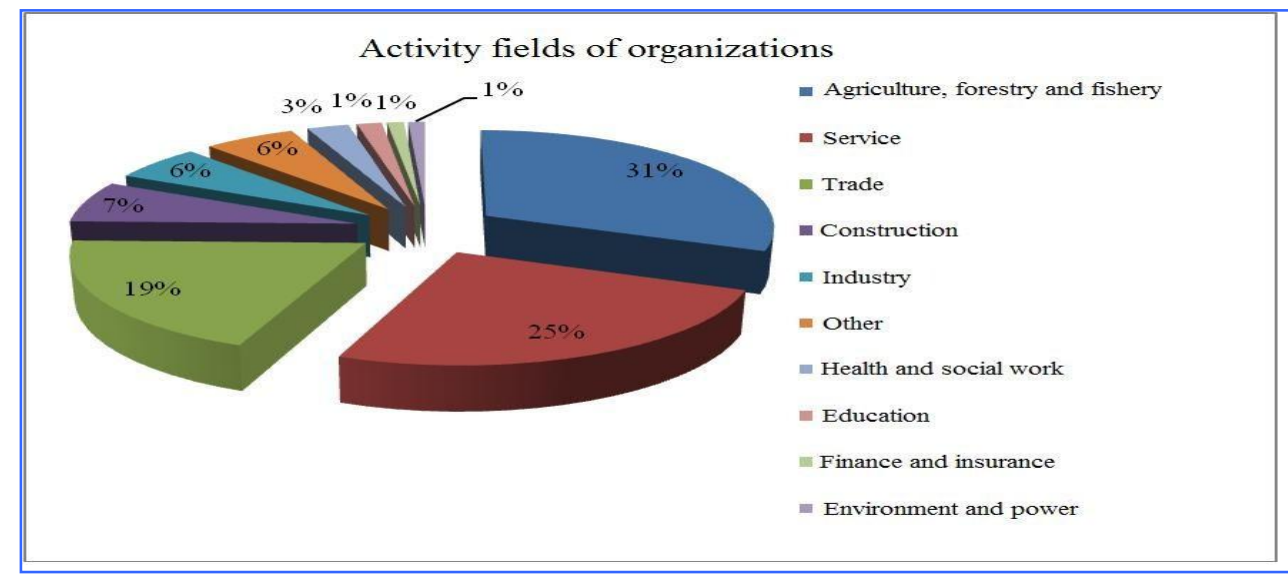

Figure 1. Activity fields of organizations in Kurzeme, year 2011

Dominating fields in the region: agriculture, forestry and fishery; service and trade. In the context of these enterprise activities also are estimated the current popularity of business support resources, necessity and effectiveness of them. 


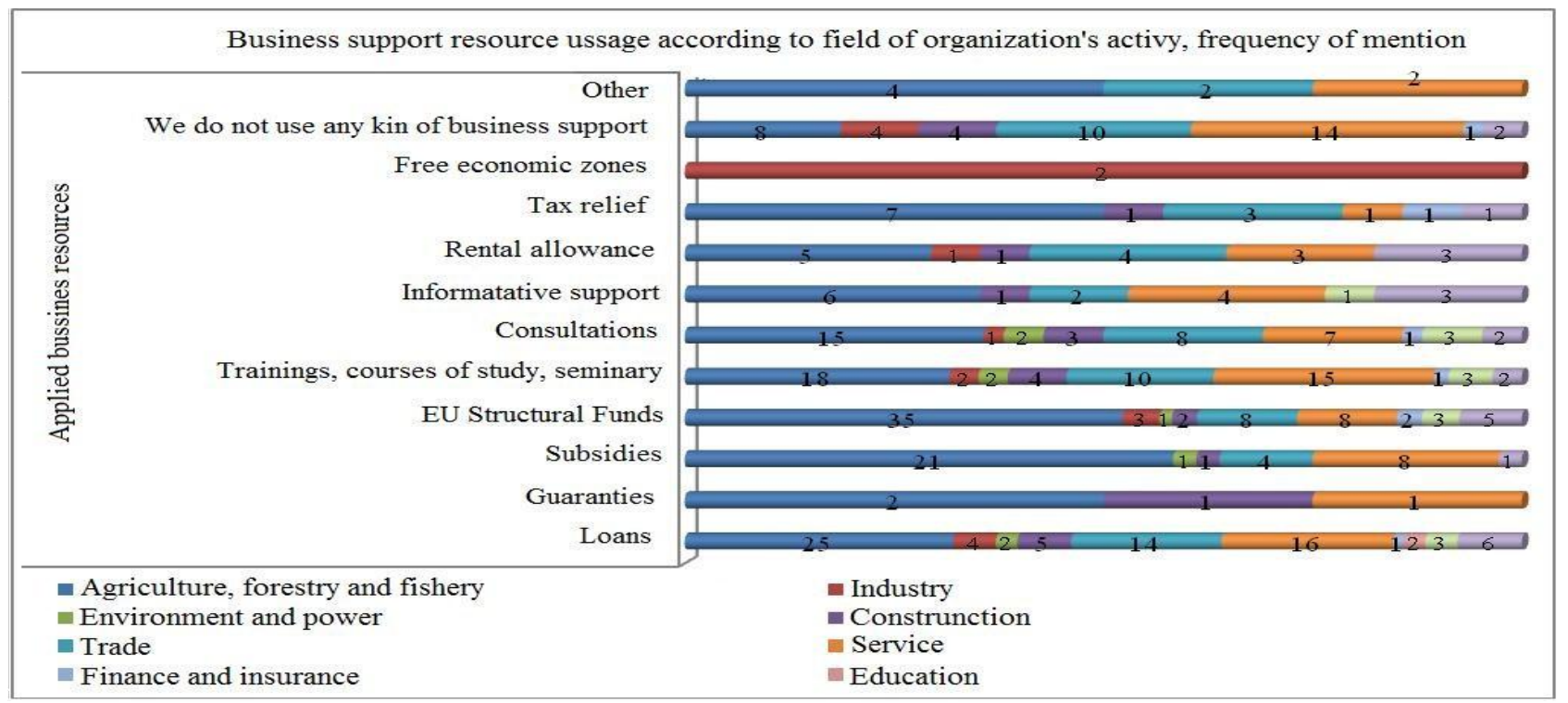

Figure 2. Support resource usage and necessity from the entrepreneur viewpoint, \%

The most commonly used support instruments are in the field of agriculture, service and trade. The least- education, finance and insurance, and in the field of environment and power. Free economic zones are used only by enterprises performing in industry field. Guaranties and other not mentioned instruments are included in the group of the most unpopular instruments.

The most widely used support instruments are loans, EU Structural Funds, trainings, courses of study, seminaries, consultations and subsidies.

In order to determine the obstructive factors of business development in frontier region, entrepreneurs were asked to evaluate them in 5-grade scale.

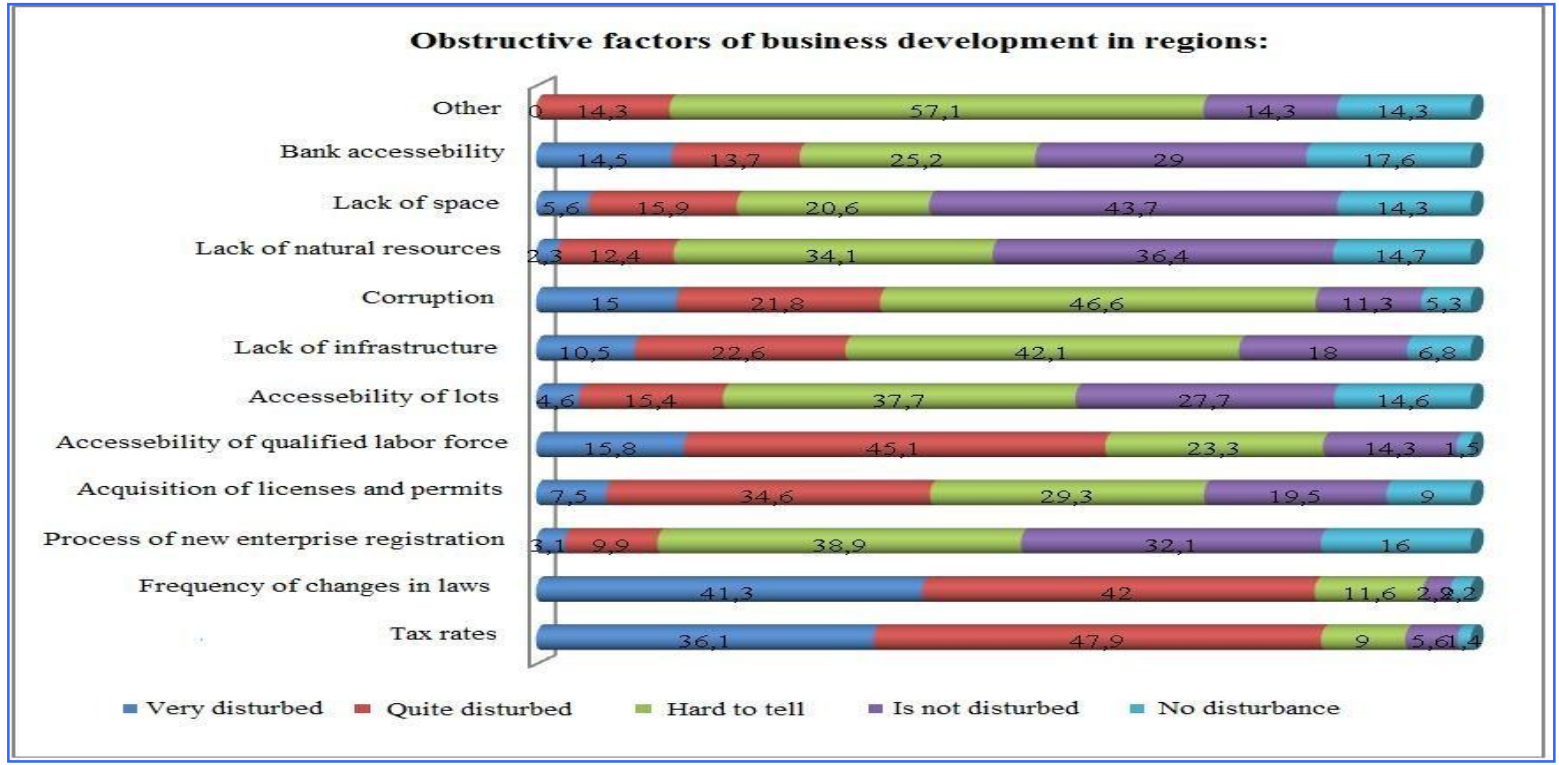

Figure 3. Obstructive factors of business development in Kurzeme, year 2011

As an obstructive factor entrepreneurs consider tax rates, frequency of changes in laws and the accessibility of qualified labor force. Seldom, but a comparatively large amount, as an obstructive factor mentions acquisition of licenses and permits, corruption and lack of infrastructure.

As the less obstructive factor entrepreneurs mentioned the lack of space and natural resources, followed by the process of new enterprise registration and bank accessibility.

During the survey, entrepreneurs estimated also the quality of available service, which is necessary for the business development. 


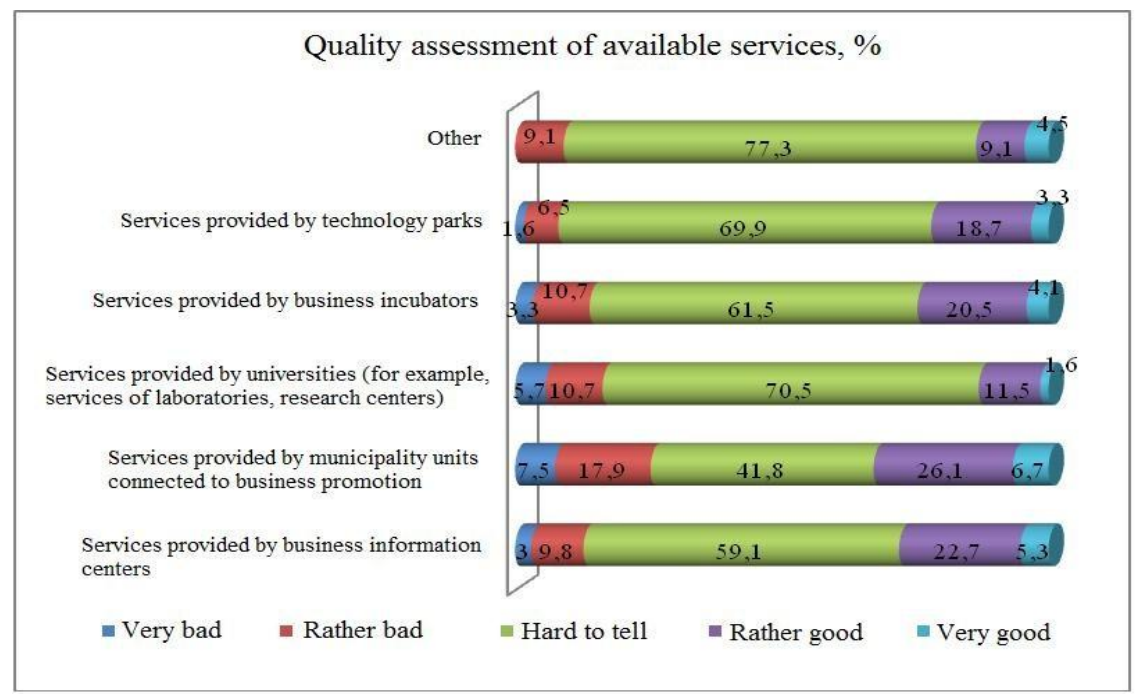

Figure 4. Quality assessment of available services in Kurzeme, year 2011

Almost one third of surveyed entrepreneurs, services provided for municipality business growth, estimated as rather good and very good, but $25.4 \%$ admitted them as very and rather bad. Services provided by business information centers, in $28 \%$ of all cases are evaluated as rather good and very good, but services provided by business incubators in $24.6 \%$ of cases are valuated positively. However, in general entrepreneurs cannot estimate the quality of available services, which are necessary for business development, emerging the problem of rare usage of them.

The survey allowed identifying such Kurzeme frontier region's business environment's strengths and weaknesses as:

Weak points: size of tax rates, frequency of changes in laws, reduction of population, ageing of population, decrease of student amount, accessibility of certain qualification professionals, unused potential of regional ports and airports, insufficiently maintained transport infrastructure, impoverishment of airport activity, reduction of non-financial investments, decrease of local market, socio-economic inequality.

Strong points: region's location, cooperation potential in fields connected to transport and tourism flows, tourism attractiveness of the region, within inhabitants increases the usage of information technologies. Explicit Latvia's and Lithuania's partnership in import and export of goods, sufficiency of natural resources, region's entrepreneur motivation for self competitiveness increase, increase of activity, usage of business support instruments.

\section{Conclusions}

With a positive sign can be estimated the fact that entrepreneurs embrace not only material supportloans, EU Structural Funds, subsidies, but also educational support- trainings, courses of study, seminaries, consultations. It approves entrepreneur willingness to acquire new knowledge, serving as a competitiveness increasing factor. As a result of analysis of changes that took place in Kurzeme region's business environment, in the research period, a visible need for analyzing region's total economic activity in context with national average politic and macroeconomic processes has raised, in order to find the most appropriate business support tools and plan the strategic development directions of region's business environment.

\section{References}

1. Reǵionu attīstība Latvijā 2009 (2010). Valsts reǵionālās attīstības aǵentūra, Rīga.

2. Reǵionu attīstība Latvijā 2010 (2011),.Valsts reg̣ionālās attīstības ağentūra, Rīga.

3. Bowman, I. (1932). Planning in Pioneer Settlement. Annals of the Association of American Geographers, Vol.22, No.2. 93-107.

4. Foreign Trade Statistics, (2011). http://www.liaa.gov.lv/jp/48638/49636/, LIAA.

5. Kurzeme region values and characteristics, Kurzeme Planning Region, (2012). http://www.kurzemesregions.lv/en/sakums/Apraksts_par_regionu/

6. Krugman, P. (1994). Competitiveness: A Dangerous Obsession. Foreign Affairs, Vol.73, No.2. 28-44.

7. Cunksa, Z.(2011). Mainīties, lai strādātu. Politika.lv, http://www.politika.lv/temas/fwd_eiropa/17126/

8. Pollmill.com. (2011). Survey. http://apklausa.lt/private/forms/survey-of-business-support-in-lithuanian-latviancrosborder-region-lu-xaxzuj6 